Supporting Information

\title{
Target-Driven Design of a Coumarinyl Chalcone Scaffold Based Novel EF2 \\ Kinase Inhibitor Suppresses Breast Cancer Growth in vivo
}

Ferah Comert Onder ${ }^{1-3}$, Nermin Kahraman ${ }^{1}$, Esen Bellur Atici ${ }^{4}$, Ali Cagir ${ }^{5}$, Hakan Kandemir ${ }^{6}$, Gizem Tatar ${ }^{7}$, Tugba Taskin Tok ${ }^{7,8}$, Goknur Kara ${ }^{1}$, Bekir Karliga ${ }^{4}$, Serdar Durdagi ${ }^{9}$, Mehmet $\mathrm{Ay}^{3, *}$ and Bulent Ozpolat ${ }^{1,10^{*}}$

${ }^{1}$ Department of Experimental Therapeutics, The University of Texas, MD Anderson Cancer Center, 1515 Holcombe Boulevard, Unit 422, Houston, TX 77030, USA, ${ }^{2}$ Department of Medical Biology, Çanakkale Onsekiz Mart University, Faculty of Medicine, 17020 Canakkale, Turkey, ${ }^{3}$ Department of Chemistry, Natural Products and Drug Research Laboratory, Çanakkale Onsekiz Mart University, Faculty of Science and Arts, 17020 Canakkale, Turkey, ${ }^{4}$ DEVA Holding A.S. Cerkezkoy, Tekirdag, Turkey, ${ }^{5}$ Izmir Institute of Technology, Department of Chemistry, Bioorganic and Medicinal Chemistry Laboratory, Turkey, ${ }^{6}$ Tekirdag Namik Kemal University, Department of Chemistry, Turkey, ${ }^{7}$ Gaziantep University, Institute of Health Sciences, Department of Bioinformatics and Computational Biology, 27310, Gaziantep, Turkey, ${ }^{8}$ Gaziantep University, Faculty of Arts and Sciences, Department of Chemistry, 27310, Gaziantep, Turkey, ${ }^{9}$ Department of Biophysics, School of Medicine, Computational Biology and Molecular Simulations Laboratory, Bahcesehir University, 34734 Istanbul, Turkey, ${ }^{10}$ Center for RNA Interference and Non-Coding RNAs, The University of Texas, MD Anderson Cancer Center, Houston, TX, USA

Correspondence: Bulent Ozpolat MD, PhD, Department of Experimental Therapeutics, The University of Texas MD Anderson Cancer Center, 1515 Holcombe Boulevard, Houston, TX 77030, USA Email: bozpolat@mdanderson.org; Mehmet Ay, PhD, Department of Chemistry, Faculty of Science and Arts, 17020 Canakkale, Turkey Email: mehmetay06@comu.edu.tr Short title: Novel EF2-Kinase inhibitor suppresses breast cancer growth

\section{\#Patent pending}




\section{Table of Contents}

Figure S1. The interaction analysis of homology model of eEF-2K with compound 2C. This compound is bound to ATP binding site of eEF-2K (blue color indicates compound 2C, yellow color indicates ATP).

Figure S2. RMSD-time plot of protein and top-pose of 2C RMSDs (based on protein structure) throughout the simulations.

Figure S3. RMSD-time plot of protein and second-top-pose of 2C RMSDs (based on protein structure) throughout the simulations.

Table S1. QPLD docking score comparison of $\mathbf{2 C}$ with other eEF-2K inhibitors.

Table S2. IFD docking score comparison of $\mathbf{2 C}$ at the clinically important kinases.

Table S3. Predicted ADME profiles of the compound 2C 


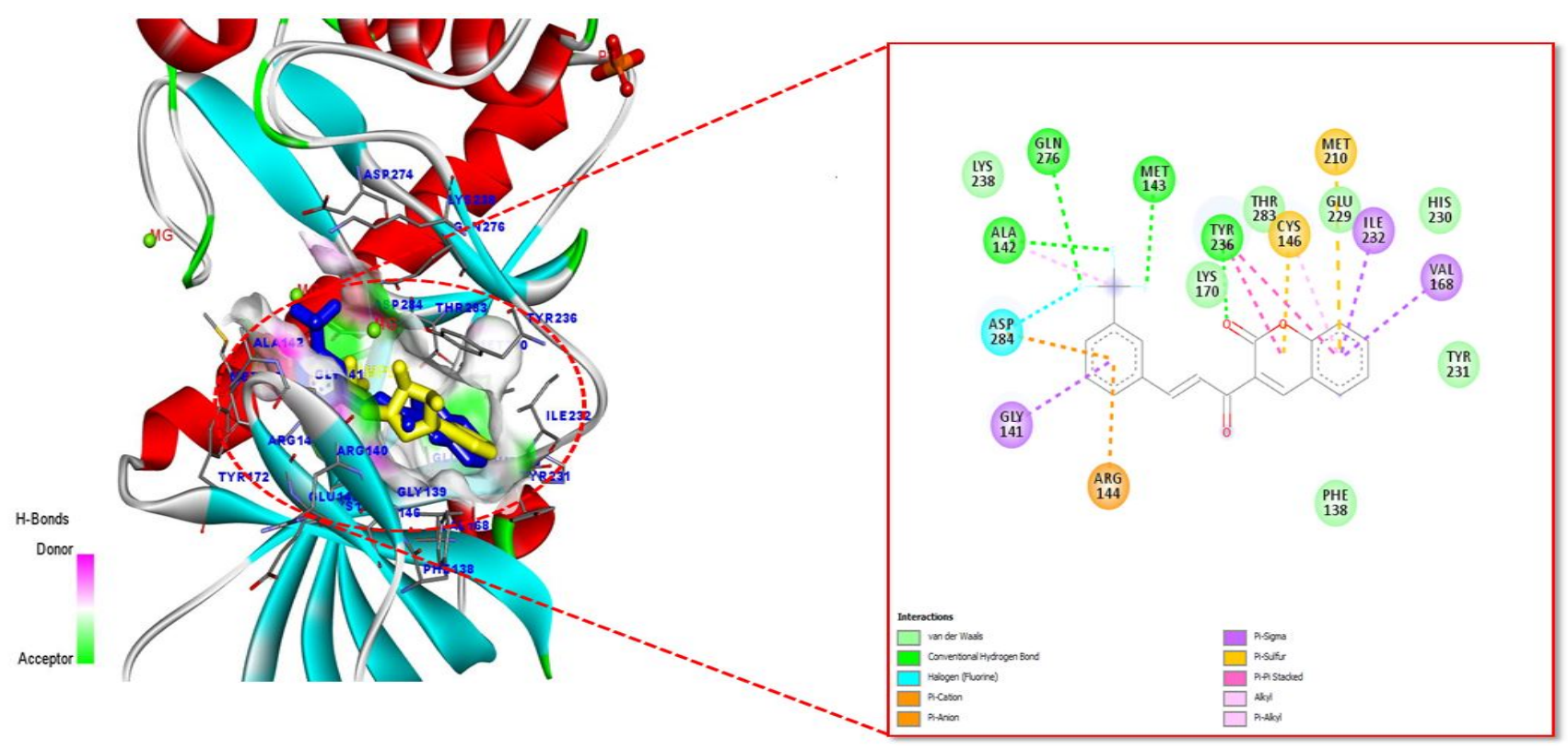

Figure S1. The interaction analysis of homology model of eEF-2K with compound 2C. This compound is bound to ATP binding site of eEF-2K (blue color indicates compound 2C, yellow color indicates ATP). 


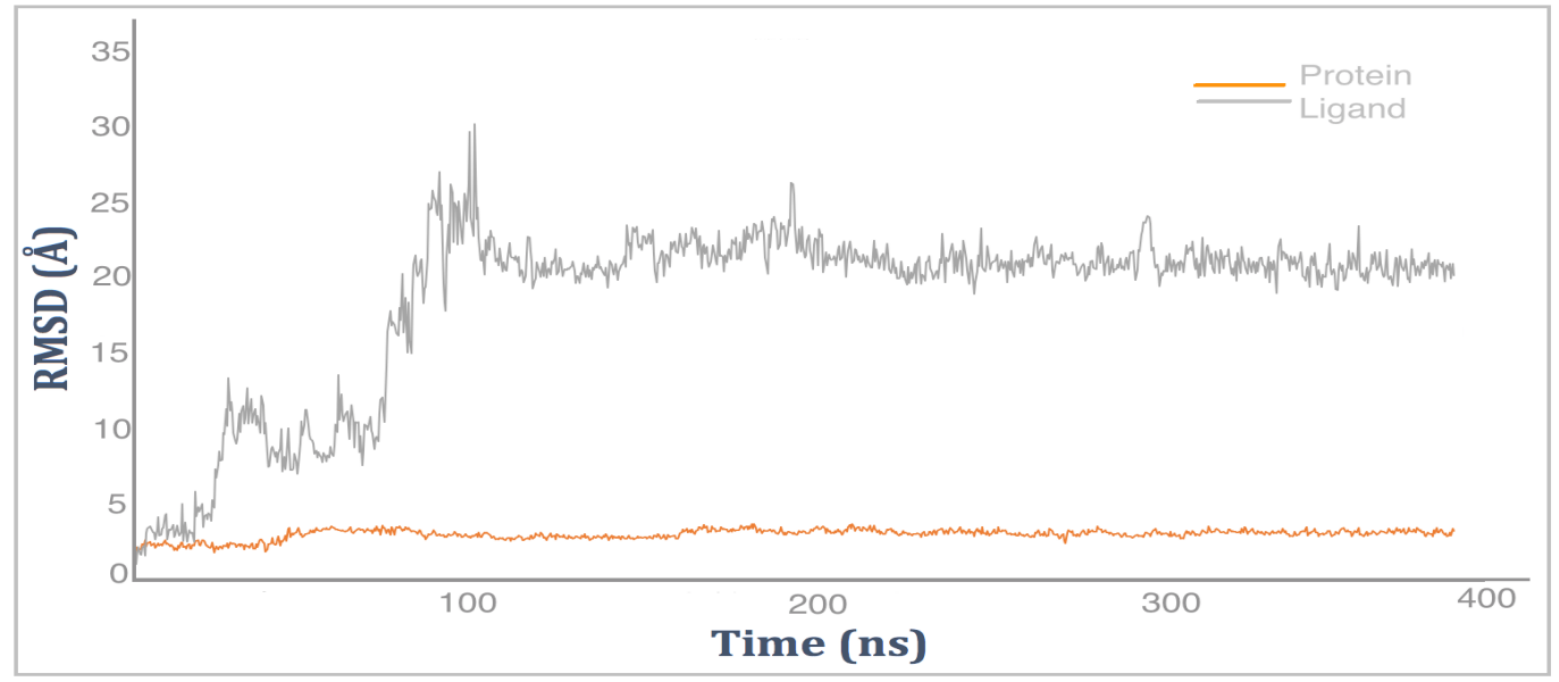

Figure S2. RMSD-time plot of protein and top-pose of 2C RMSDs (based on protein structure) throughout the simulations. 


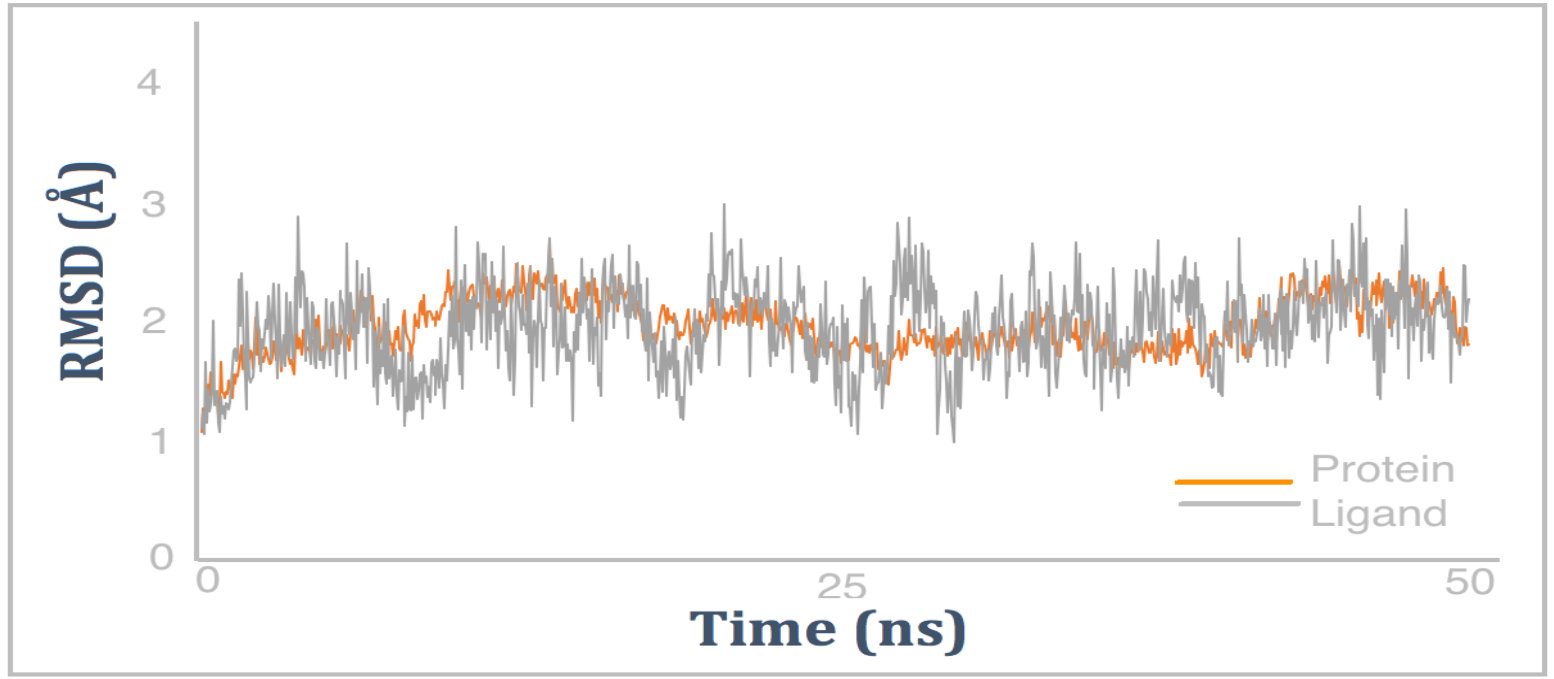

Figure S3. RMSD-time plot of protein and second-top-pose of 2C RMSDs (based on protein structure) throughout the simulations. 
Table S1. QPLD docking score comparison of 2C with other eEF-2K inhibitors.

\begin{tabular}{|l|l|}
\hline eEF-2K inhibitors & $\begin{array}{l}\text { QPLD scores } \\
\text { (kcal/mol) }\end{array}$ \\
\hline A484954 & -5.62 \\
\hline NH125 & -4.50 \\
\hline TX-1918 & -5.53 \\
\hline Rottlerin & -8.26 \\
\hline Compound 2C & -7.69 \\
\hline
\end{tabular}

Table S2. IFD docking score comparison of $\mathbf{2 C}$ at the clinically important kinases.

\begin{tabular}{|l|l|l|}
\hline Kinase & Protein & $\begin{array}{l}\text { Docking Score } \\
\text { (kcal/mol) }\end{array}$ \\
\hline eEF2K & $\begin{array}{l}\text { MHCKA-based } \\
\text { homology model } \\
\text { structure }\end{array}$ & -9.95 \\
\hline PI3Kalpha & 5 SXJ & No pose \\
\hline AKT (Protein kinase B) & 2XH5 & -6.39 \\
\hline PKC-delta & 1YRK & -6.43 \\
\hline MAPKAP kinase 2 (MK2) & 1NY3 & -6.67 \\
\hline AXL tyrosine kinase & $5 \mathrm{U} 6 \mathrm{~B}$ & -7.11 \\
\hline YES1 Tyrosine-protein kinase & $\begin{array}{l}\text { Based on c-Src } \\
(1 \mathrm{Y} 57)\end{array}$ & -7.54 \\
\hline $\begin{array}{l}\text { RNA-activated protein kinase, } \\
\text { PKR }\end{array}$ & $6 \mathrm{D} 3 \mathrm{~L}$ & -7.58 \\
\hline $\begin{array}{l}\text { PIM3 Serine/threonine-protein } \\
\text { kinase }\end{array}$ & $\begin{array}{l}\text { Based on PIM-1 } \\
\text { kinase (5N4V) }\end{array}$ & -8.29 \\
\hline SR protein kinase 1 (SRPK1) & 5MXX & -9.94 \\
\hline $\begin{array}{l}\text { Checkpoint kinase 2 (Chk2) } \\
\text { 2XK9 }\end{array}$ & -10.23 \\
\hline
\end{tabular}


Table S3. Predicted ADME profiles of the compound 2C

\begin{tabular}{|l|l|l|l|l|l|l|}
\hline $\begin{array}{l}\text { eEF-2K } \\
\text { inhibitor }\end{array}$ & $\begin{array}{l}\text { BBB, log } \\
\text { ratio }^{(1)}\end{array}$ & G-LogP & $\begin{array}{l}\text { Prot-bind, } \\
\%^{(3)}\end{array}$ & $\begin{array}{l}\text { WSol, log } \\
\mathrm{mg} / \mathrm{L}^{(4)}\end{array}$ & $\begin{array}{l}\text { hERG- } \\
\text { inh, pKi } \\
(5)\end{array}$ & $\begin{array}{l}\text { SERT- } \\
\text { inh, pKi } \\
(6)\end{array}$ \\
\hline Comp. 2C & -0.52 & 3.51 & 82.65 & 0.88 & -0.27 & 0.27 \\
\hline
\end{tabular}

(1) Blood brain barrier penetration model. The data is expressed as log values of the ratio of the metabolite concentrations in brain and plasma. Cutoff is -0.3 . Larger values indicate that the metabolite is more likely to enter the brain. Reference: Thomson Reuters. Model description: N=107, R2=0.89, RMSE $=0.26$.

(2) Lipophilicity, $\log$ of compound octanol-water distribution. Cutoffs are -0.4 to 5.6. Values greater than 5.6 correspond to overly hydrophobic compounds. Reference: Syracuse Research, PHYSPROP database. Model description: N=13474, R2=0.95, RMSE $=0.21$.

(3) Human serum protein binding, \%. Cutoff is $50 \%$. A value of more than $95 \%$ is highly bound, less than $50 \%$ is a low binding metabolite. Reference: Thummel and Shen, 2001 in Goodman \& Gilman's The Pharmacological Basis of Therapeutics. Model description: $\mathrm{N}=265, \mathrm{R} 2=0.909, \mathrm{RMSE}=10.11$.

(4) Water solubility at $25^{\circ} \mathrm{C}, \log \mathrm{mg} / \mathrm{L}$. Cutoffs are from 2 to 4 . An acceptable level of solubility is project dependent. Reference: Syracuse Research, PHYSPROP database. Model description: $\mathrm{N}=2871,2=0.91, \mathrm{RMSE}=0.54$.

(5) Human hERG (human ether a-go-go-related gene) channel inhibition, pKi (uM). Cutoff is -1.7 . The higher the value, the higher the inhibition activity. Lower values are preferable. Reference: Thomson Reuters. Model description: N=196, R2=0.93, $\mathrm{RMSE}=0.23$.

(6) Human serotonin transporter inhibition, pKi (uM). Cutoff is -1.7. The higher the value, the higher the inhibition activity of the metabolite. Thomson Reuters. Model description: $\mathrm{N}=256, \mathrm{R} 2=0.91, \mathrm{RMSE}=0.36$. 